\title{
Analisis dan Perancangan Sistem Informasi Inventory Sparepart Kapal Berbasis Web : Studi Kasus Asia Group Pangkalpinang
}

\author{
Hengki ${ }^{[1]}$, Susan Suprawiro ${ }^{[2]}$ \\ STMIK Atma Luhur, Jl. Jend. Sudirman, Selindung, Pangkalpinang, Kep. Bangka Belitung \\ Program Studi Sistem Informasi ${ }^{[1][2]}$ \\ hengki@atmaluhur.ac.id ${ }^{[1]}, 1322500123 @$ mahasiswa.atmaluhur.ac.id ${ }^{[2]}$
}

\begin{abstract}
Abstrak - ASIA Group adalah perusahaan yang bergerak di bidang jasa pertambangan laut yang merupakan mitra PT. Timah (Persero) Tbk. Saat ini sistem yang berjalan masih terdapat kekurangan seperti pencarian data, pencatatan data, dan pembuatan laporan yang cukup lama. Hal ini dapat memperlambat karyawan dalam pendataan inventory sparepart. Penelitian ini bertujuan merancang sebuah sistem inventory berbasis web yang dibutuhkan perusahaan sehingga mampu meningkatkan kinerja karyawan ASIA Group dalam pengelolaan data sparepart kapal. Dalam menganalisa dan merancang sistem ini menggunakan model waterfall yang berorientasi objek dan berbasis web yang menggunakan PHP sebagai bahasa pemrograman dan Mysql sebagai database. Alat pengembangan sistem yang digunakan dalam penelitian ini menggunakan Unified Modelling Language (UML). Sistem digunakan untuk mempercepat proses pengolahan data sparepart oleh User Cabang dan pencetakan laporan sehingga perusahaan dapat lebih efisien dan efektif. Sistem inventory ini berbasis web sehingga dapat digunakan dengan mudah, user friendly dan mengelola data sparepart yang bisa dilakukan secara fleksibel dengan berbagai menu yang tersedia untuk User Cabang dan Manajer Purchasing.
\end{abstract}

Kata Kunci-Inventory, Web, Sparepart, PHP, Mysql

\section{Pendahuluan}

Pada era globalisasi sekarang ini kebutuhan teknologi dan informasi yang efektif dan efisien sangat dibutuhkan sesuai dengan perkembangan teknologi yang ada. Pada perkembangan teknologi informasi yang ada saat ini dapat melakukan pengolahan data dengan mudah, dapat menghasilkan suatu informasi yang di butuhkan dengan akurat dan mengefektifkan waktu, serta biaya yang di keluarkan lebih efisien.

Dalam sebuah instansi saat ini, komputer merupakan sebuah alat atau sarana yang sangat dibutuhkan untuk membantu dalam menyelesaikan pekerjaan perusahaan di bidangnya masing-masing. Hal ini tidak dapat dipungkiri lagi, karena dengan menggunakan komputer pekerjaan kantor dapat diselesaikan dengan cepat.

ASIA Group adalah perusahaan yang bergerak di bidang jasa pertambangan laut yang merupakan mitra PT. Timah (Persero) Tbk. ASIA Group sendiri memiliki beberapa perusahaan yang bergerak di bidang dan pengelolaan manajemen yang sama. Saat ini sistem pengelolaan sparepart untuk persediaan di kapal tidak terpantau sehingga banyak terjadi kesalahan pada saat permintaan sparepart. Sistem yang berjalan di perusahaan ini seperti permintaan sparepart, pengeluaran sparepart, pembelian sparepart, pencatatan stok sparepart masih menggunakan pencatatan manual.

Berdasarkan permasalahan yang ada pada ASIA Group penulis mengambil sebuah gambaran dari permasalahan pengendali inventory untuk mengontrol item sparepart yang masuk di ASIA Group. Sebelumnya, pada perusahaan tersebut mencatat item sparepart masuk dan keluar masih menggunakan sistem non-komputerisasi sehingga memakan banyak waktu untuk mengetahui stok sparepart yang ada didalam inventory. Maka untuk mengatasi permasalahan sistem inventory sparepart kapal di ASIA Group, penulis menggunakan model waterfall dan melakukan penelitian dengan judul "Analisis dan Perancangan Sistem Informasi Inventory Sparepart Kapal Berbasis Web : Studi Kasus ASIA Group Pangkalpinang".

\section{LANDASAN TEORI}

\section{A. Sistem Informasi}

Sistem adalah kumpulan dari elemen-elemen yang berinteraksi untuk mencapai suatu tujuan tertentu.

Informasi adalah data yang diolah menjadi bentuk yang lebih berguna dan lebih berarti bagi yang menerimanya.

Sistem Informasi adalah suatu sistem di dalam suatu organisasi yang mempertemukan kebutuhan pengelolaan transaksi harian, mendukung operasi, bersifat manajerial, dan kegiatan strategi dari suatu organisasi dan menyediakan pihak luar tertentu dengan laporan-laporan yang dibutuhkan. [1]

\section{B. Inventory}

Menurut Kamus Besar Bahasa Indonesia Inventory adalah stok bahan yang digunakan untuk memudahkan produksi atau untuk memuaskan pelanggan yang meliputi bahan baku (raw materials), barang dalam proses (in-process goods), dan barang jadi (finished goods). 
Inventory yaitu barang - barang yang disimpan untuk digunakan atau dijual pada masa atau periode yang akan datang. Secara umum inventory berfungsi untuk mengelola persediaan barang dagangan yang selalu mengalami perubahan jumlah dan nilai melalui transaksi - transaksi pembelian dan penjualan. [2]

\section{Sparepart Kapal}

Sparepart kapal adalah suatu barang kapal yang terdiri dari lebih dari satu komponen yang membentuk satu kesatuan dan memiliki fungsi tertentu setiap alat berat.

Secara umum sparepart dapat dibagi menjadi dua, yaitu :

1) Sparepart baru yaitu komponen yang masih dalam kondisi baru dan belum pernah dipakai sama sekali kecuali sewaktu dilakukan pengetesan.

2) Sparepart bekas atau copotan yaitu komponen yang pernah dipakai untuk periode tertentu dengan kondisi :

a) Masih layak pakai yaitu secara teknis komponen tersebut masih dapat dipergunakan atau mempunyai umur pakai.

b) Tidak layak pakai yaitu secara teknis komponen tersebut sudah tidak dapat lagi dipakai walaupun dilakukan perbaikan atau rekondisi.

\section{Web}

World Wide Web atau WWW atau juga dikenal dengan WEB adalah salah satu layanan yang didapat oleh pemakai komputer yang terhubung ke internet. Website atau situs dapat diartikan sebagai kumpulan halaman-halaman yang digunakan untuk menampilkan informasi teks, gambar diam atau gerak, animasi, suara, dan atau gabungan dari semuanya itu baik yang bersifat statis maupun dinamis yang membentuk satu rangkaian bangunan yang saling terkait dimana masingmasing dihubungkan dengan jaringan-jaringan halaman (hyperlink).

\section{E. Waterfall}

Model waterfall ini sebenarnya adalah "Linear Sequential Model", yang sering dsebut juga dengan "classic life cycle" atau model waterfall. Waterfall atau air terjun adalah model yang dikembangkan untuk pengembangan perangkat lunak, membuat perangkat lunak. Model berkembang secara sistematis dari satu tahap ke tahap lain dalam model seperti air terjun. [3]

\section{Waterfall model}

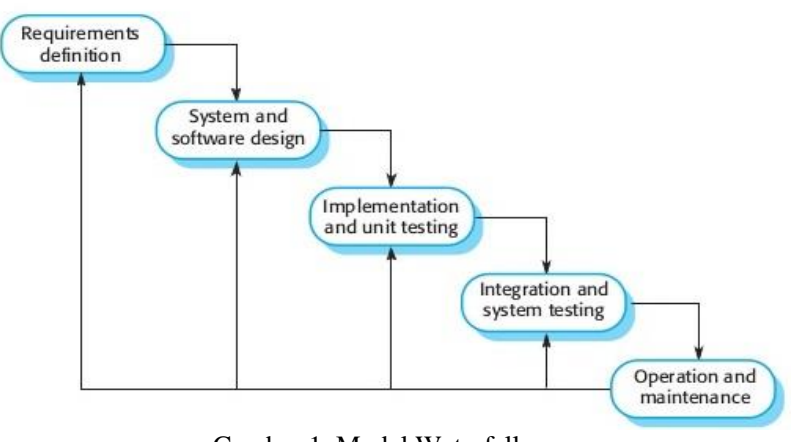

Gambar 1. Model Waterfall
Berikut adalah penjelasan dari tahap-tahap yang dilakukan di dalam model ini menurut Pressman :

1) Requirements Definition

Seluruh kebutuhan software harus bisa didapatkan dalam fase ini, termasuk didalamnya kegunaan software yang diharapkan pengguna dan batasan software. Informasi ini biasanya dapat diperoleh melalui wawan cara, survei atau diskusi. Informasi tersebut dianalisis untuk mendapatkan dokumentasi kebutuhan pengguna untuk digunakan pada tahap selanjutnya.

2) System and Software Design

Tahap ini dilakukan sebelum melakukan coding. Tahap ini bertujuan untuk memberikan gambaran apa yang seharusnya dikerjakan dan bagaimana tampilannya. Tahap ini membantu dalam menspesifikasikan kebutuhan hardware dan sistem serta mendefinisikan arsitektur sistem secara keseluruhan.

3) Implementation and Unit Testing

Dalam tahap ini dilakukan pemrograman. Pembuatan software dipecah menjadi modul-modul kecil yang nantinya akan digabungkan dalam tahap berikutnya. Selain itu dalam tahap ini juga dilakukan pemeriksaaan terhadap modul yang dibuat, apakah sudah memenuhi fungsi yang diinginkan atau belum.

4) Integration and System Testing

Di tahap ini dilakukan penggabungan modul-modul yang sudah dibuat dan dilakukan pengujian ini dilakukan untuk mengetahui apakah software yang dibuat telah sesuai dengan desainnya dan masih terdapat kesalahan atau tidak.

5) Operation and Maintenance

Ini merupakan tahap terakhir dalam model waterfall. Software yang sudah jadi dijalankan serta dilakukan pemeliharaan. Pemeliharaan termasuk dalam memperbaiki kesalahan yang tidak ditemukan pada langkah sebelumnya. Perbaikan implementasi unit sistem dan peningkatan jasa sistem sebagai kebutuhan baru. [4]

\section{F. Unified Modelling Language (UML)}

Unified Modelling Language (UML) adalah sebuah "bahasa" yang telah menjadi standar dalam industri untuk visualisasi, merancang dan mendokumentasikan sistem piranti lunak. UML menawarkan sebuah standar untuk merancang model sebuah sistem. [5]

\section{G. Perancangan Berorientasi Objek}

Tahap-tahap metodologi berdasarkan Sistem Development Life Cycle (SDLC) digunakan dengan memperhatikan karakteristik khusus berorientasi objek, diantaranya adalah :

1) Analisis

Analisis berorientasi objek dimulai dengan menyatakan suatu masalah, analis membuat model situasi dari dunia nyata, menggambarkan sifat yang penting. Analis harus bekerja dengan pihak yang membutuhkan sistem untuk memahami masalah tersebut. Model analisis adalah abstraksi yang ringkas dan tepat dari apa yang harus 
dilakukan oleh sistem, dan bagaimana melakukannya. Objek dalam model harus merupakan konsep domain dari aplikasi, dan bukan merupakan implementasi komputer seperti struktur data. Model yang baik harus dipahami dan ditanggapi oleh ahli aplikasi. Empat kesulitan yang merupakan gangguan utama sistem adalah memahami problem domain, komunikasi antara pihak yang berkaitan, perubahan kontinyu, dan reuse (penggunaan kembali).

\section{2) Desain}

Desain Berorientasi Objek atau Object Oriented Design (OOD) merupakan tahap lanjutan setelah Analisis Berorientasi Objek dimana tujuan sistem diorganisasikan ke dalam sub-sistem berdasar struktur analisis dan arsitektur yang dibutuhkan. System Designer menentukan karakteristik penampilan secara optimal, menentukan strategi memecahkan masalah, dan menentukan pilihan alokasi sumberdaya. Sebagai contoh, System Designer mungkin menentukan perubahan pada screen untuk workstation yang memerlukan kecepatan serta resolusi lebih tinggi. Desain model berdasarkan model analisa tetapi berisi detail implementasi. Fokus dari object design adalah perencanaan struktur data dan algoritma yang diperlukan untuk implementasi setiap kelas. Objek domain aplikasi dan objek domain komputer dijelaskan dengan menggunakan konsep dan notasi berorientasi objek yang sama.

\section{3) Implementasi}

Kelas, objek, dan relasinya dikembangkan dalam tahap pembuatan desain objek yang pada akhirnya diterjemahkan ke dalam bahasa pemrograman, basis data, dan implementasi perangkat keras. Hal yang penting dalam tahap implementasi adalah mengikuti penggunaan perangkat lunak yang baik.

Diagram - diagram UML yang digunakan penulis dalam merancang sistem berorientasi objek adalah :

\section{1) Activity Diagram}

Activity Diagram adalah Sebuah diagram alur kerja yang menjelaskan berbagai kegiatan pengguna (atau sistem), orang yang melakukan masing-masing aktivitas, dan aliran sekuensial dari aktivitas-aktivitas tersebut.

\section{2) Use Case Diagram}

Use Case Diagram adalah salah satu jenis diagram pada UML yang menggambarkan interaksi antara sistem dan aktor, use case diagram juga dapat men-deskripsikan tipe interaksi antara si pemakai sistem dengan sistemnya.

\section{3) Package Diagram}

Package diagram yaitu salah satu jenis diagram pada UML digunakan untuk mengelompokan kelas dan juga menunjukan bagaimana elemen model akan disusun serta mengambarkan ketergantungan antara paket-paket.

\section{4) Class Diagram}

Class diagram yaitu salah satu jenis diagram pada UML yang digunakan untuk menampilkan kelas-kelas maupun paket-paket yang ada pada suatu sistem yang nantinya akan digunakan.

\section{5) Deployment Diagram}

Deployment Diagram yaitu salah satu diagram pada UML yang menunjukan tata letak suatu sistem secara fisik, dapat juga dikatakan untuk menampilkan bagian-bagian software yang terdapat pada hardware dan digunakan untuk menerapkan suatu sistem dan hubungan antara komponen hardware.

\section{6) Sequence Diagram}

Sequence Diagram yaitu adalah satu jenis diagram pada UML yang menjelaskan interaksi objek yang berdasarkan urutan waktu, sequence diagram juga dapat menggambarkan urutan atau tahapan yang harus dilakukan untuk dapat menghasilkan sesuatu seperti pada use case diagram.

\section{H. Macromedia Dreamweaver}

Macromedia Dreamweaver adalah sebuah HTML editor profesional untuk mendesain secara visual dan mengelola situs web maupun halaman web. Bilamana kita menyukai untuk berurusan dengan kode-kode HTML secara manual atau lebih menyukai bekerja dengan lingkungan secara visual dalam melakukan editing.

Teknologi Dreamweaver Roundtrip HTML mampu mengimpor dokumen HTML tanpa perlu memformat ulang kode tersebut dan kita dapat menggunakan Dreamweaver pula untuk membersihkan dan memformat ulang HTML bila kita menginginkannya.

\section{I. $M y S Q L$}

MySQL adalah sistem manajemen database SQL yang bersifat Open Source dan paling populer saat ini. Sistem Database MySQL mendukung beberapa fitur seperti multithreaded, multi-user, dan SQL database management system (DBMS). Database ini dibuat untuk keperluan sistem database yang cepat, handal dan mudah digunakan.

\section{Metodologi Penelitian}

\section{A. Model Waterfall}

Aktifitas pengembangan sistem yang penulis lakukan sesuai dengan model pengembangan perangkat lunak di atas adalah:

\section{1) Perencanaan Sistem}

Pada tahap ini ada beberapa hal penting yang perlu dilakukan dalam pembuatan sistem inventory ini yaitu pengumpulan data untuk menggali informasi yang dibutuhkan untuk membuat sistem informasi inventory sparepart di ASIA Group Pangkalpinang. Adapun metode 
pengumpulan data yang penulis gunakan adalah sebagai berikut :

\section{a) Wawancara}

Melakukan komunikasi tanya jawab secara langsung dengan karyawan ASIA Group Pangkalpinang mengenai sejarah terbentuknya ASIA Group Pangkalpinang, struktur organisasi, serta sistem inventory yang berjalan di ASIA Group Pangkalpinang.

\section{b) Observasi}

Dalam hal ini penulis langsung melihat atau mengadakan pengamatan ke bagian-bagian yang ada hubungannya dengan sistem informasi inventory sparepart sekaligus pengumpulan dokumen-dokumen yang digunakan.

\section{c) Studi Pustaka}

Menggunakan beberapa buku sebagai referensi, untuk memperoleh penjelasan yang bersifat teori yang berhubungan dengan masalah yang diteliti.

\section{d) Studi Literatur}

Studi literatur digunakan untuk mengumpulkan data dari penelitian terdahulu, pembelajaran dari berbagai macam literatur dan dokumen seperti buku, jurnal dan teori-teori yang mendukung penelitian, tools yang akan digunakan dan data penunjang lainnya yang berkaitan dengan sistem informasi penjualan berbasis web.

\section{2) Analisis Sistem}

Di dalam analisis sistem terdapat beberapa langkah dasar yang harus dilakukan adalah sebagai berikut :

\section{a) Activity Diagram}

Bagian dari penggambaran sistem secara fungsional menjelaskan proses-proses logika atau fungsi.

\section{b) Analisis Keluaran}

Berisi mengenai gambaran keluaran yang dihasilkan oleh sistem yang dianalisa.

\section{c) Analisis Masukan}

Berisi mengenai gambaran masukan yang dihasilkan oleh sistem yang dianalisa.

\section{d) Identifikasi Kebutuhan}

Berisi mengenai identifikasi kebutuhan / usulan yang diperlukan oleh sistem berdasarkan hasil analisis keluaran dan masukan sistem yang berjalan pada ASIA Group Pangkalpinang.

\section{e) Use Case Diagram}

Use Case Diagram ini juga mendeskripsikan apa yang akan dilakukan oleh sistem.

\section{f) Package Diagram}

Penulis mengelompokkan elemen-elemen model dari Use Case Diagram.

\section{3) Perancangan Sistem}

Dalam perancangan suatu sistem informasi langkah yang perlu dilakukan diantaranya adalah perancangan sistem. Pada bab ini akan dibahas bagaimana perancangan dari sistem informasi yang akan dibangun.

\section{a) Rancangan Basis Data}

Penulis menggunakan Entity Relationship Diagram, dimana Entity Relationship Diagram memodelkan data apa yang ada, tujuan utama dari penggambaran ERD adalah menunjukkan objek data (entitas) dan hubungannya (relationship) terhadap entitas yang ada sehingga dapat dihasilkan file-file yang akan dibentuk.

\section{b) Class Diagram}

Class Diagram menggambarkan struktur dan hubungan antar objek-objek yang ada pada sistem.

\section{c) Deployment Diagram}

Deployment Diagram menggambarkan rinci bagaimana komponen di-deploy dalam infrastruktur sistem, dimana komponen akan terletak bagaimana kemampuan jaringan pada lokasi tersebut.

\section{d) Sequence Diagram}

Sequence diagram merupakan gambaran interaksi antar masing-masing objek pada setiap use case dalam urutan waktu.

\section{B. Metode Berorientasi Objek}

Metode pengembangan perangkat lunak yang di gunakan adalah pendekatan dengan Object Oriented yang menggunakan OOA (Object Oriented Analysis) dan OOD (Object Oriented Design) yang di visualisasikan dengan UML dan di antara nya adalah sebagai berikut : Activity Diagram, Use Case Diagram, Package Diagram, Class Diagram, Deployment Diagram, dan Sequence Diagram.

\section{Tools Pengembangan Sistem}

Penulis menggunakan UML (Unified Modelling Language) sebagai tools untuk perancangan dan pengembangan aplikasinya. Adapun tools UML (Unified Modelling Language) yang penulis gunakan dalam pengembangan sistem ini terdiri dari :
a. Activity Diagram
b. Use Case Diagram
c. Package Diagram
d. Class Diagram
e. Deployment Diagram
f. Sequence Diagram 
D. Langkah-Langkah Penelitian

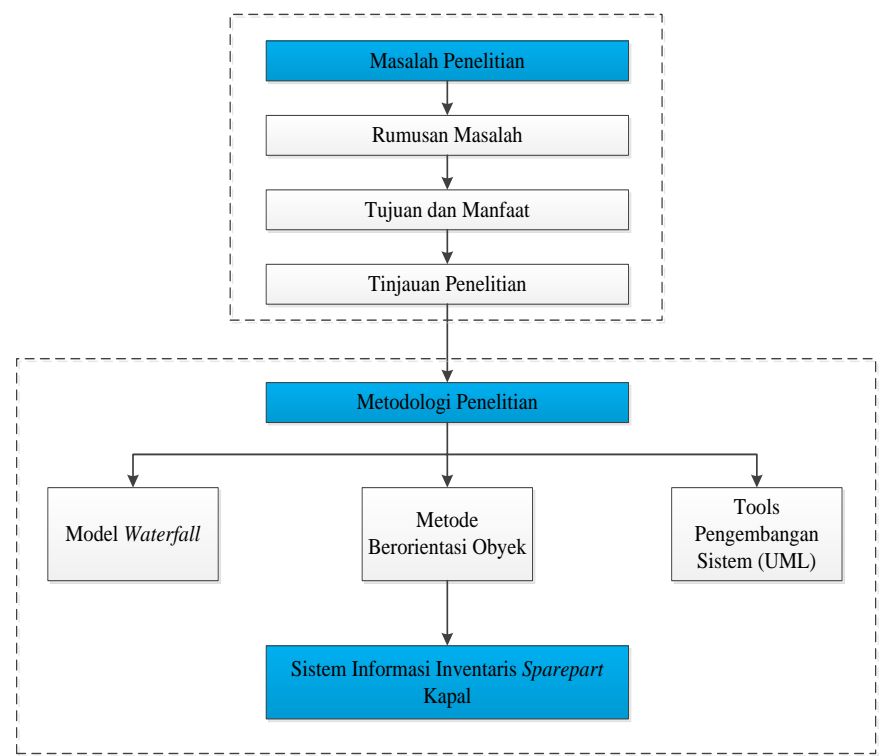

Gambar 2. Langkah-Langkah Penelitian

\section{HASIL DAN PEMBAHASAN}

\section{A. Sejarah Perusahaan}

ASIA Group adalah sebuah perusahaan yang berdiri sejak tahun 2006 dengan memulai usaha pada bidang pertambangan laut mitra PT. Timah (Persero) Tbk. Kantor pusat ASIA Group berada di Jakarta, tepatnya berada di Jl. Gunung Sahari 2 No. 14 E, Jakarta Pusat sedangkan kantor cabang berada di Perumahan Bangka Asri Blok C-2, Bangka Tengah. Pada awalnya, ASIA Group hanya memiliki satu perusahaan yaitu PT. Alam Sejahtera Indonesia Abadi. Seiring berjalannya waktu, perusahaan mulai berkembang dan membangun perusahaan lainnya yang bergerak di bidang yang sama. Maka itulah perusahaan-perusahaan ini lebih dikenal dengan nama ASIA Group. Perusahaan - perusahaan ini dikelola dengan manajemen yang sama. Hingga saat ini sedikitnya ada 5 perusahaan aktif yang berada di dalam ASIA Group.

\section{B. Proses Bisnis}

Prosedur yang dilakukan dalam Sistem Informasi Inventory Sparepart ASIA Group Pangkalpinang adalah sebagai berikut :

\section{1) Proses Pendataan Sparepart}

Pimpinan menyerahkan data sparepart dan kategori sparepart kepada Admin Cabang. Admin Cabang mencatat nama sparepart dan kategori sparepart.

\section{2) Proses Pendataan Kapal}

Pimpinan menyerahkan data kapal kepada Admin Cabang. Admin Cabang mencatat data kapal tersebut.

\section{3) Proses Pendataan Supplier}

Pimpinan menyerahkan data Supplier kepada Admin Cabang. Admin cabang mencatat data Supplier.

\section{4) Proses Pemesanan Sparepart}

Manajer Operasional memberi konfirmasi sparepart yang akan dipesan kepada Admin Cabang secara lisan. Admin Cabang membuat PO Sparepart. PO Sparepart ditandatangani oleh Admin Cabang dan Manajer Operasional. PO Sparepart yang sudah ditandatangani di serahkan ke Manajer Purchasing. Manajer Purchasing menandatangani PO Sparepart kemudian memberi konfirmasi kepada Kepala Pembelian. Jika PO Sparepart disetujui, Kepala Pembelian akan memberi konfirmasi persetujuan PO Sparepart kepada Manajer Purchasing. Jika PO Sparepart tidak disetujui, Kepala Pembelian akan membatalkan PO Sparepart dan memberi konfirmasi pembatalan PO Sparepart kepada Manajer Purchasing. Manajer Purchasing memberi konfirmasi pembatalan PO Sparepart kepada Admin Cabang dan Manajer Operasional.

\section{5) Proses Pembelian Sparepart}

Manajer Purchasing akan mencari sparepart sesuai PO Sparepart ke Supplier. Supplier akan menyediakan sparepart sesuai dengan PO Sparepart dan membuatkan Nota yang selanjutnya akan dikirim ke kantor ASIA Group Pangkalpinang dan diterima oleh Admin Cabang.

\section{6) Proses Pengeluaran Sparepart}

Manajer Operasional memberi konfirmasi sparepart yang akan dibawa ke masing-masing kapal kepada Admin Cabang. Admin Cabang akan membuat form Pengeluaran Sparepart sesuai dengan sparepart yang akan dibawa ke kapal dan menandatanganinya. Admin Cabang mengecek kembali Form Pengeluaran Sparepart dengan sparepart yang akan dibawa. Manajer Operasional menandatangani form Pengeluaran Sparepart dan menyerahkan kembali kepada Admin Cabang. Admin Cabang menandatanganinya dan menyimpannya.

\section{7) Proses Retur Sparepart}

Manajer Operasional melaporkan sparepart yang akan di retur kepada Admin Cabang, setelah itu Admin Cabang membuatkan Nota Retur. Manajer Operasional menandatangani Nota Retur. Manajer Operasional menyerahkan Nota Retur kepada Manajer Purchasing. Manajer Purchasing menyerahkan sparepart retur dan Nota Retur yang sudah ditandatangani Manajer Purchasing kepada Supplier.

\section{8) Proses Pembuatan Laporan Data Sparepart}

Pada akhir bulan Admin Cabang merekap semua Form Pengeluaran Sparepart. Setelah semua data selesai di rekap, Admin Cabang membuat Laporan Data Sparepart. Manajer Purchasing dan Admin Cabang menandatangani Laporan Data Sparepart dan selanjutnya Admin Cabang menyerahkan Laporan kepada pimpinan.

\section{Use Case Diagram}

Berikut ini adalah Use Case Diagram Sistem Informasi Inventory Sparepart Kapal pada ASIA Group Pangkalpinang : 


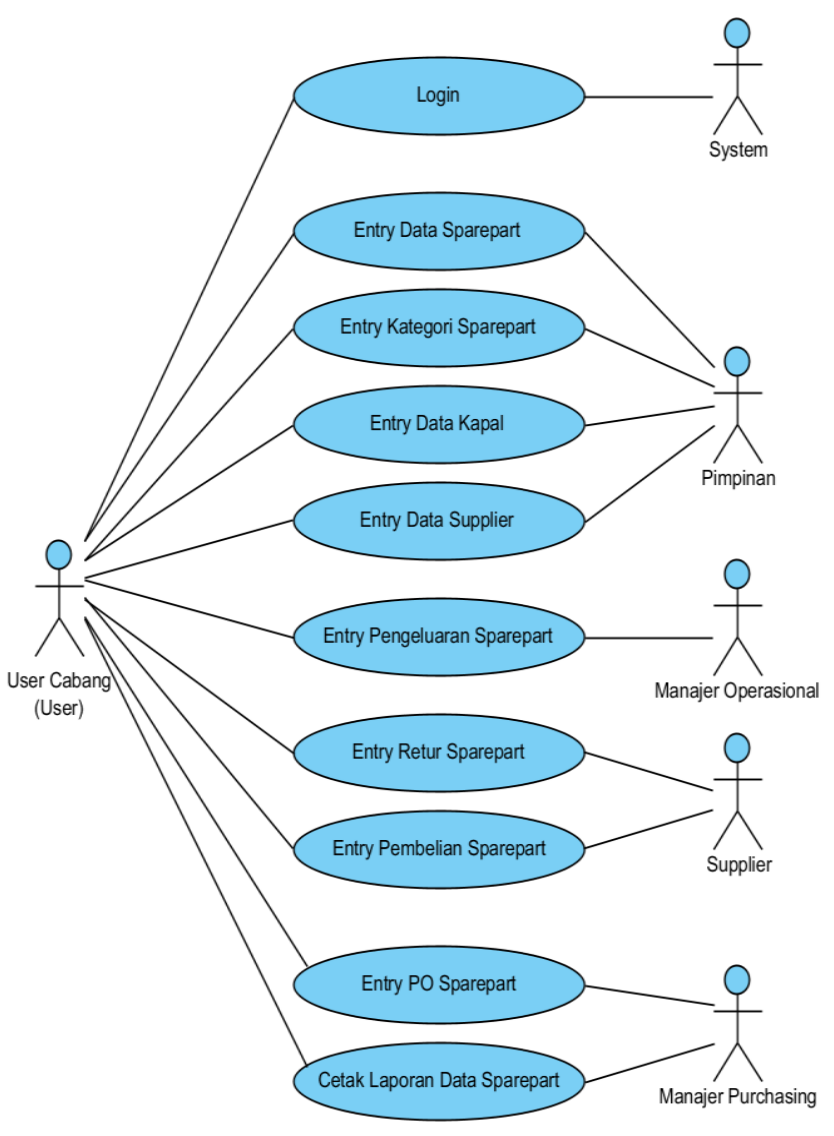

Gambar 3. Use Case Diagram berdasarkan Actor Admin Cabang

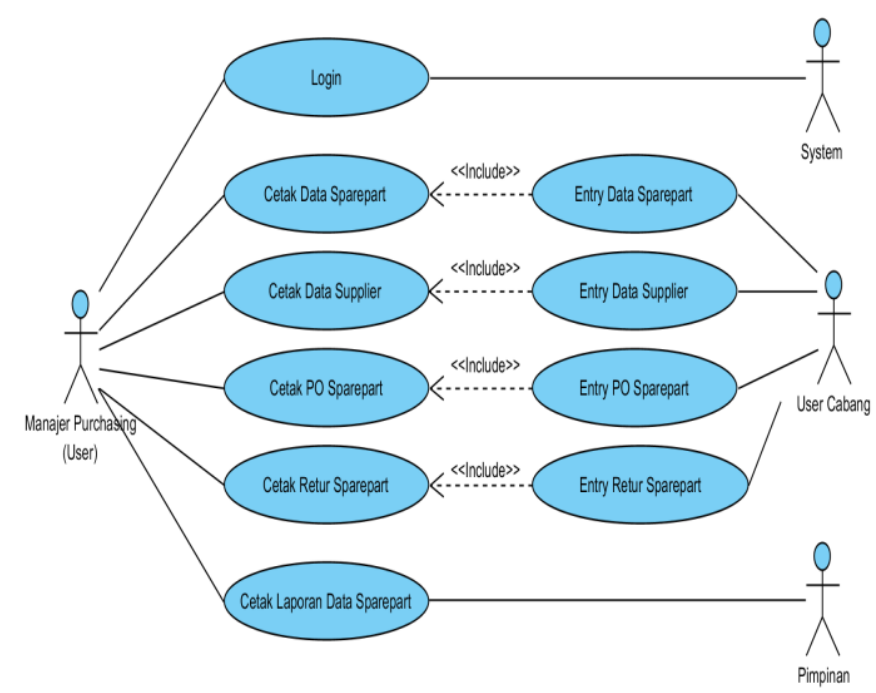

Gambar 4. Use Case Diagram berdasarkan Actor Manajer Purchasing

D. Package Diagram

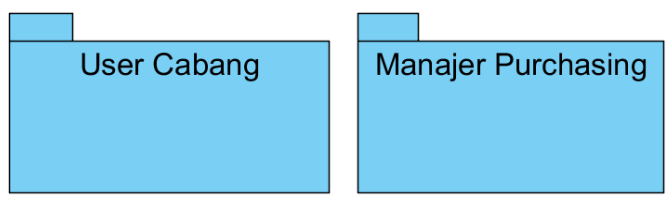

Gambar 5. Package Diagram

\section{E. Entity Relationship Diagram (ERD)}

Berikut ini adalah penjelasan dari Entity Relationship Diagram (ERD) :

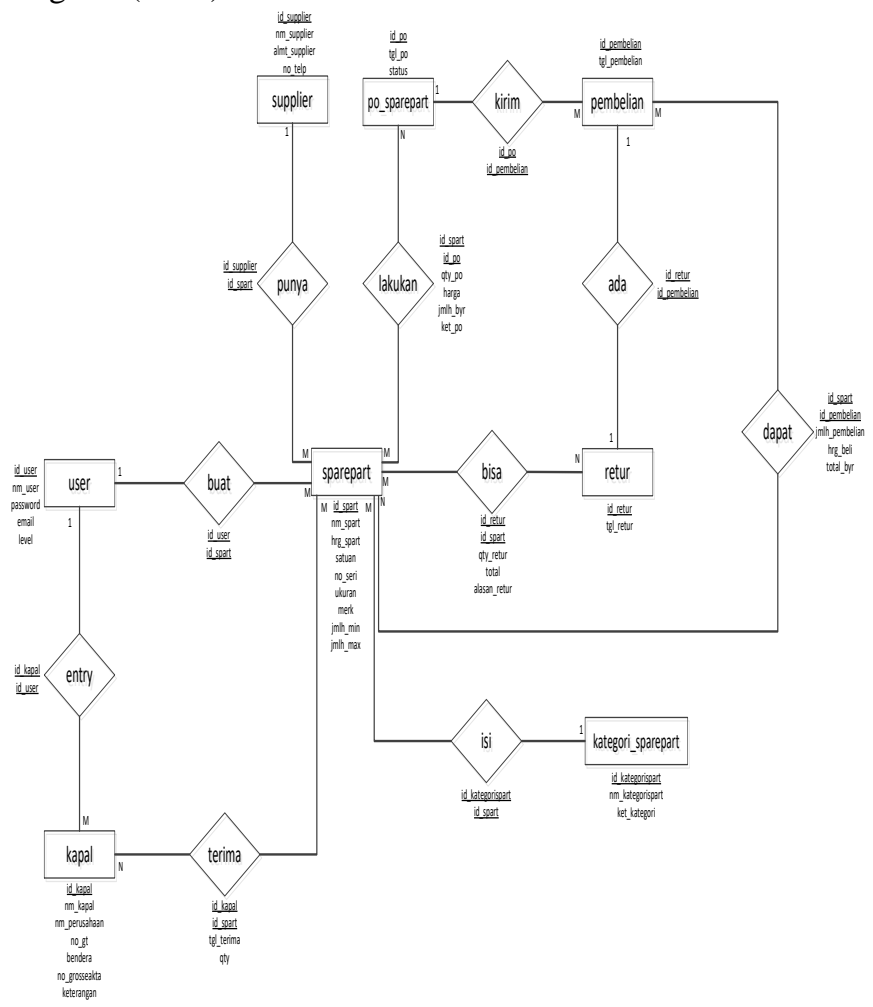

Gambar 6.Entity Relationship Diagram (ERD)

\section{F. Logical Record Structure (LRS)}

Berikut ini adalah penjelasan dari Logical Record Structure (LRS):

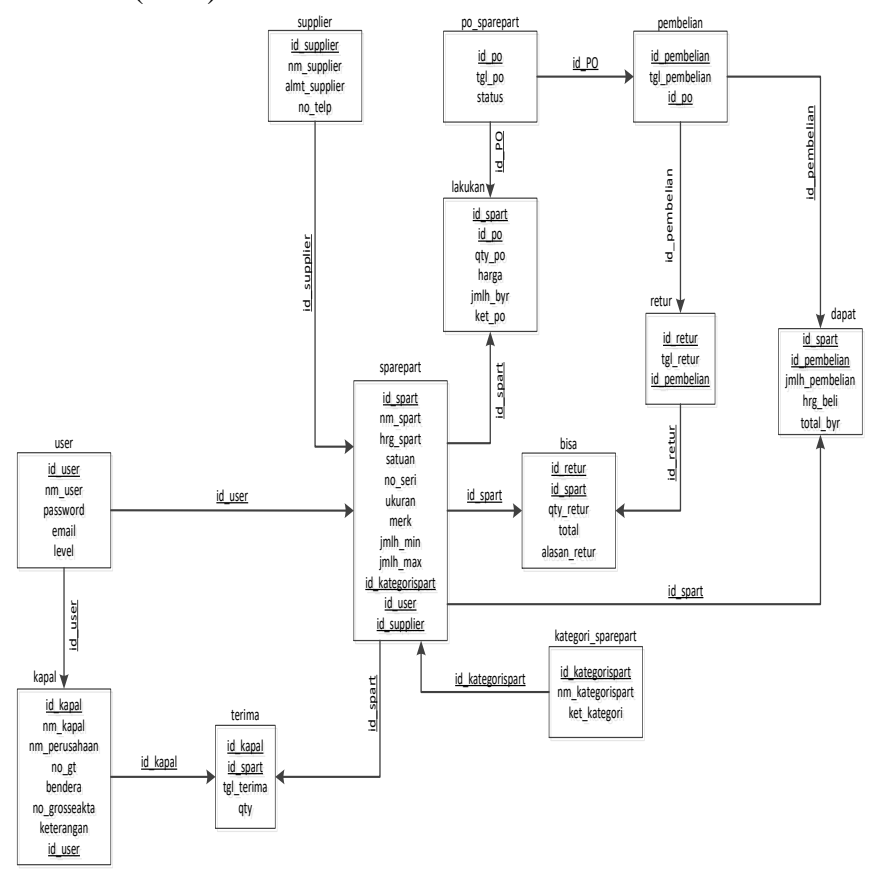

Gambar 7. Logical Record Structure (LRS) 


\section{G. Rancangan keluaran}

Rancangan keluaran ini dimaksudkan memberi gambaran mengenai keluaran dari sistem informasi yang diusulkan. Rancangan keluaran yang dihasilkan pada Sistem Informasi Inventory Sparepart Kapal pada ASIA Group Pangkalpinang adalah sebagai berikut :

- PO Sparepart.

- Laporan Data Sparepart.

\section{H. Rancangan Masukan}

Rancangan masukan yang dihasilkan pada Sistem Informasi Inventory Sparepart Kapal pada ASIA Group Pangkalpinang adalah sebagai berikut :

- Data Sparepart.

- Kategori Sparepart.

- Data Kapal

- Data Supplier.

- Pembelian Sparepart.

- Pengeluaran Sparepart.

- Retur Sparepart.

\section{Class Diagram}

Class diagram pada sistem informasi Inventory sparepart kapal pada ASIA Group secara umum dapat digambarkan sebagai berikut:

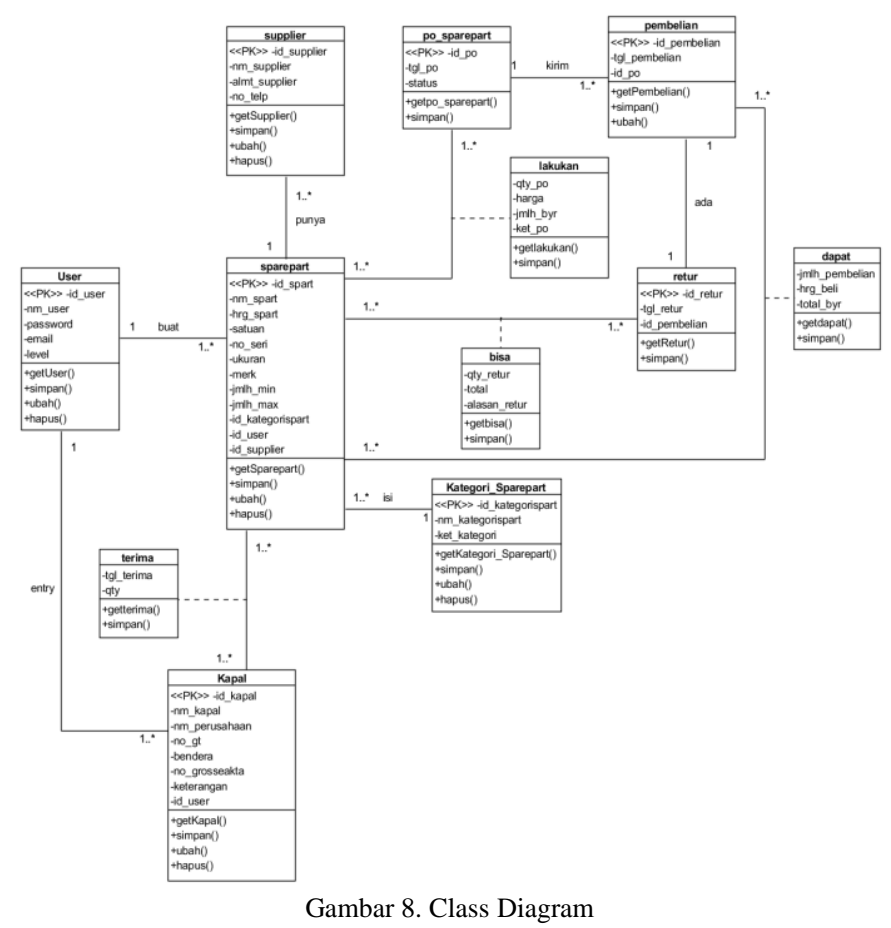

\section{J. Deployment Diagram}

Berikut ini adalah Deployment Diagram untuk sistem informasi sparepart kapal pada ASIA Group Pangkalpinang, aplikasi yang dibuat merupakan berbasis web. Node utama terdiri dari Web Server, Database Server, dan client.

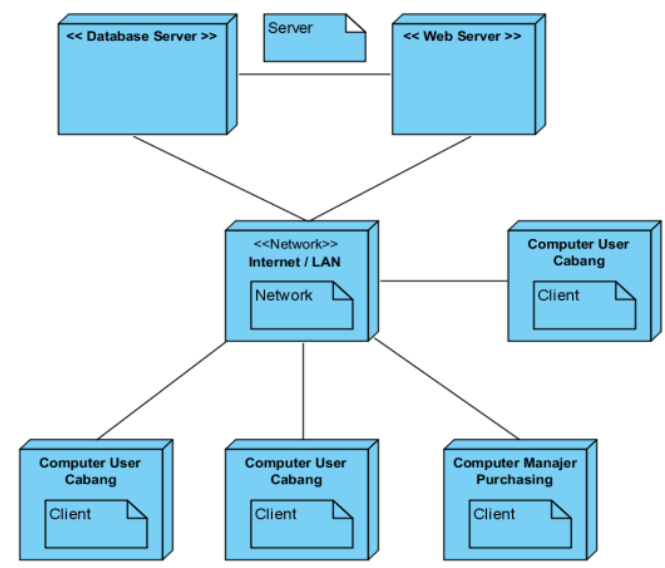

Gambar 9. Deployment Diagram

\section{K. Rancangan Antar Muka}

Berikut ini merupakan beberapa rancangan antarmuka Web Inventory ASIA Group Pangkalpinang :

1) Form Login

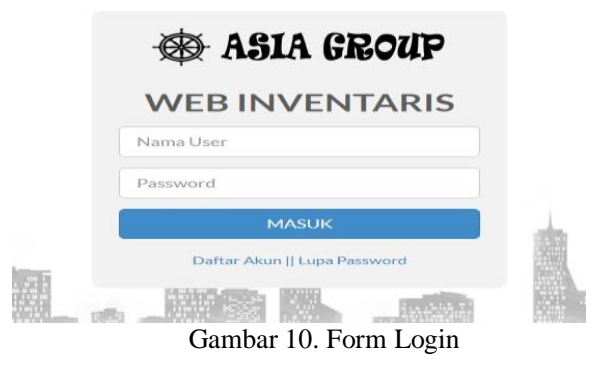

2) Form Menu Utama

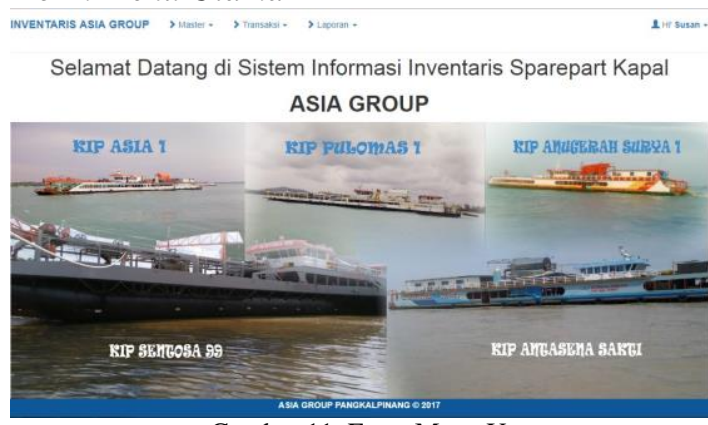

Gambar 11. Form Menu Utama

3) Form Entry Data Supplier

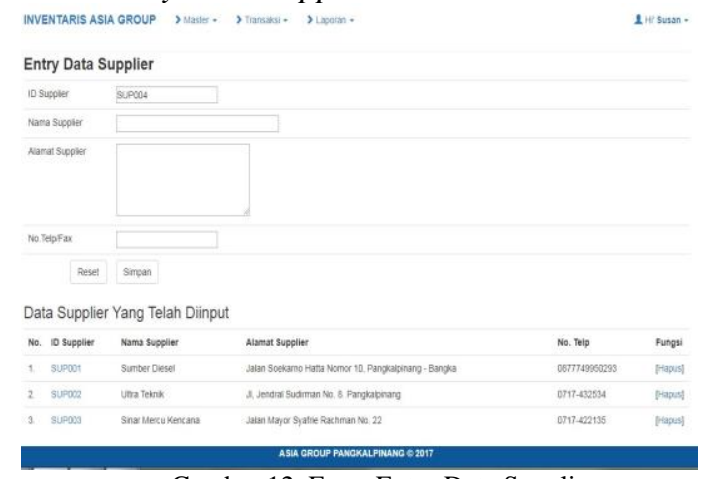

Gambar 12. Form Entry Data Supplier 
4) Form Entry Kategori Sparepart

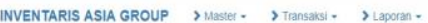

Entry Kategori Sparepart

ID Kateopon sparean Katros

Kategon Sparepart

Keterangan

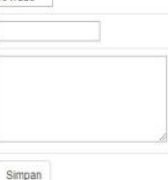

Reset Smpan

Kategori Sparepart Yang Sudah Diinput

No. IO Kastegorn Sparopart Kategori Sparepart

katoor

katoo2

oll

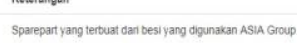

Sparepart yang bejenenis oll

Gambar 13. Form Entry Kategori Sparepart

\section{5) Form Entry Data Kapal}

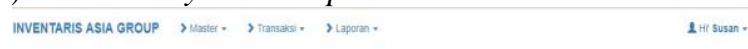

Entry Data Kapal

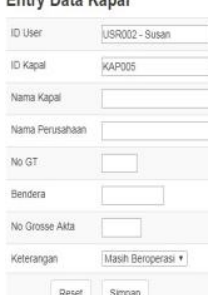

Reset Sirgen

Data Kapal Yang telah Diinput

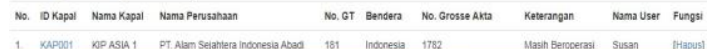

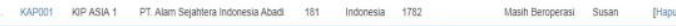

Gambar 14. Form Entry Data Kapal

6) Form Entry PO Sparepart

INVENTARIS ASIA GROUP > Master - ITranaksi v > >laporan v 2H Susan

Entry PO Sparepart

ID PO Sparearat P0002

Tanggal PO Sparepart 2017-06-25

Stans S URGENT

Nama Sparepeat Massian Nama Sparepart

10 Sparseart

Nama Suppler

Satuan

No Seni

Ukuran

Merk

Harga Sparepart

Quantity

Total Penbajaran

Keterangan

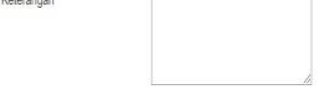

Tambah

ID Sparepart Nama Sparepart Satuan No Seri Ukuran Merk Harga aty Total Bayar Keterangan Nama Suppler

Reset Simpan

Gambar 15. Form Entry PO Sparepart
7) Form Entry Pembelian Sparepart

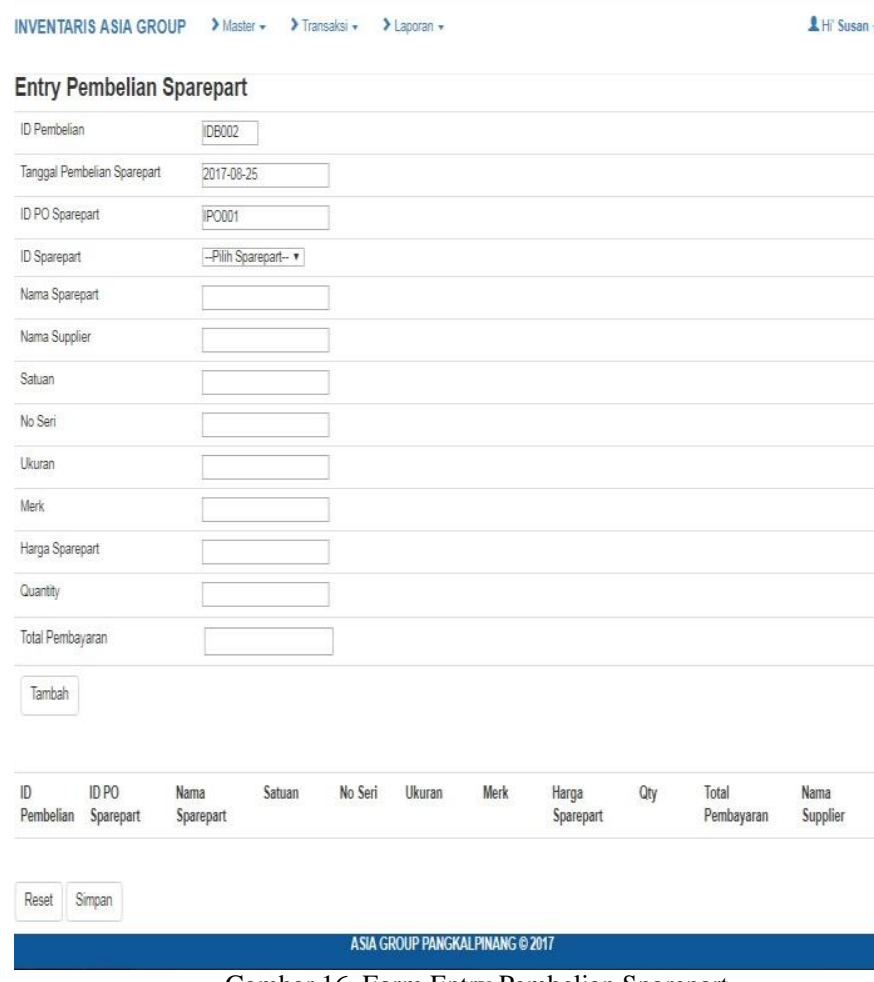

Gambar 16. Form Entry Pembelian Sparepart

8) Form Entry Retur Sparepart

INVENTARIS ASIA GROUP > Master v T Transaksi v TLaporan .

2Hi Susan .

Entry Retur Sparepart

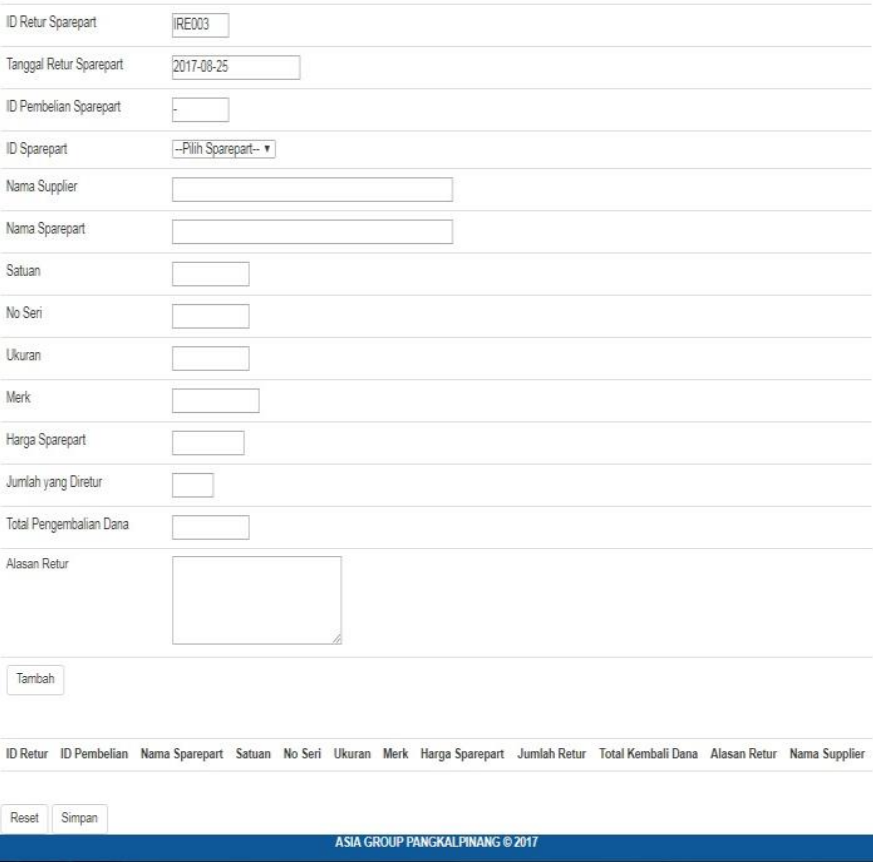

Gambar 17. Form Entry Retur Sparepart 
9) Form Entry Pengeluaran Sparepart

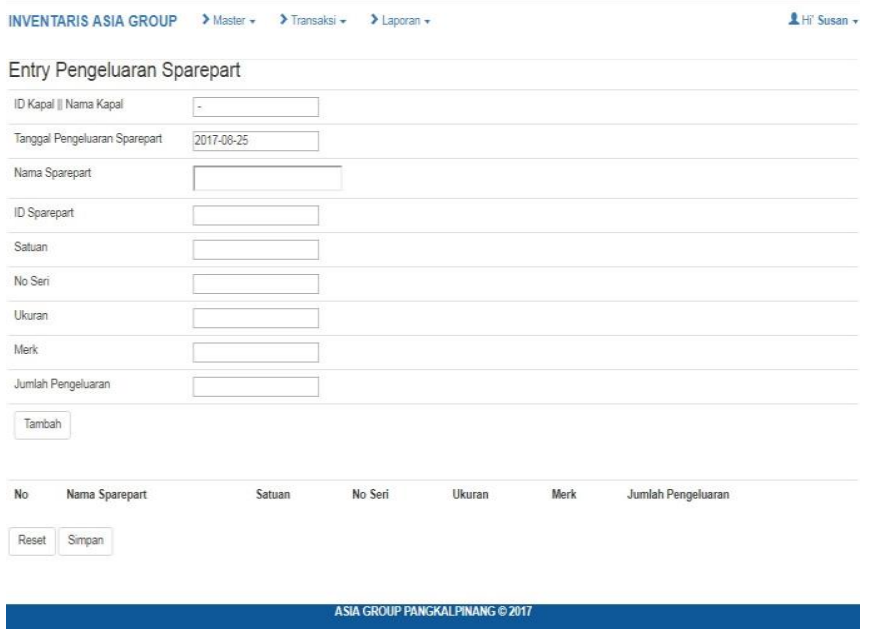

Gambar 18. Form Entry Pengeluaran Sparepart

\section{PENUTUP}

\section{A. Kesimpulan}

Dari pembahasan yang telah diuraikan sebelumnya, dapat diambil beberapa kesimpulan yang berkaitan dengan Sistem Informasi Inventory Sparepart Kapal Berbasis Web pada ASIA Group Pangkalpinang yaitu sebagai berikut:

- Aplikasi Sistem Informasi Inventory Sparepart Kapal yang berbasis Web dan user friendly dapat memudahkan karyawan dalam mengolah data sparepart kapal dengan menggunakan Model Pengembangan Perangkat Lunak waterfall, Metode Pengembangan Perangkat Lunak berorientasi objek, dan tools Unified Modelling Language (UML).

- Adanya sistem yang terhubung dengan database, dapat mempermudah dan mempercepat kerja karyawan dalam menyimpan serta mengelola data yang berhubungan dengan sparepart kapal.

- Laporan Data Sparepart dapat dibuat dengan mudah, cepat, dan akurat karena terhubung dengan database sehingga dapat disajikan dengan tepat waktu.

- Sistem Informasi Inventory Sparepart Kapal yang berbasis Web akan mempermudah dalam penginputan data sehingga kecil sekali kemungkinan terjadinya kesalahan dalam menginput data sparepart kapal.

\section{B. Saran}

Dari hasil kesimpulan yang telah penulis paparkan diatas, maka penulis mencoba memberikan saran-saran yang berhubungan dengan Sistem Informasi Inventory Sparepart Kapal Berbasis Web dan bermanfaat bagi ASIA Group Pangkalpinang, maka langkah yang diperlukan dalam membangun sistem komputerisasi sangatlah penting adalah:

- Dibuatnya sistem pembayaran Invoice pembelian sparepart dan penambahan fungsi-fungsi lainnya.

- Diadakan pelatihan karyawan tentang penggunaan aplikasi web Inventory tersebut.

- Diharapkan melakukan back-up terhadap data secara periodik untuk menjaga hal-hal yang tidak diinginkan.

- Mengingat banyaknya data-data yang diperlukan sebaiknya sudah layak menerapkan sistem jaringan (Local Area Network) untuk mempercepat proses pengolahan data.

\section{DAFTAR PUSTAKA}

[1] Deni, M., 2011, Analisa dan Rancangan Sistem Informasi Pengadaan Barang dengan Metodologi Berorientasi Objek : Studi Kasus PT. Liga Indonesia, Skripsi, Fakultas Teknologi Informasi, Universitas Budi Luhur, Jakarta.

[2] Arisma, S., 2010, Pengembangan Sistem Informasi Inventory pada PT. Dwiwarna Inti Sejahtera, Skripsi, Program Sarjana Ilmu Komputer, Universitas Islam Negeri Syarif Hidayatullah, Jakarta.

[3] Muharto dan Arisandy, A. M.Kom, 2016, Metode Penelitian Sistem Infomasi : Mengatasi Kesulitan Mahasiswa dalam Menyusun Proposal Penelitian, Deepublish, Yogyakarta.

[4] Carlos, E. Otero, 2012, Software Engineering Design : Theory and Practice, Taylor \& Francis Group, Boca Raton

[5] Adi, N., 2009. Rekayasa Perangkat Lunak Menggunakan UML \& Java, Andi Offset, Yogyakarta.

[6] Hengki, 2017. Business Intelligence Guna Mendukung Keputusan Strategis Ketua Program Studi Dengan Model Fast. Jurnal Informatika Global Vol 8, No 1.

[7] S. H. Saputra dan Hengki, 2016. Analisis Pengaruh Biaya Perkuliahan, Biaya Promosi Dan Faktor Eksternal (Uncontrollable) Terhadap Penerimaan Jumlah Mahasiswa Baru Di Kampus STMIK Atma Luhur Pangkalpinang. Jurnal Sisfokom Vol 5, No 1. 